Studia Judaica 19 (2016), nr 2 (38), s. 301-316

doi:10.4467/24500100STJ.16.014.6225

\title{
ŹRÓDłA
}

Maciej Szkółka

\section{Ostatnie auto da fé w Europie? Sprawa Żyda Borocha Lejbowa i kapitana-lejtnanta Aleksandra Woznicyna oraz jej konsekwencje}

\author{
THE LAST AUTO-DA-FÉ IN EUROPE? \\ THE CASE OF THE JEWISH MERCHANT BOROCH LEIBOV AND \\ CAPTAIN-LIEUTENANT ALEXANDER VOZNITSYN AND ITS CONSEQUENCES
}

\begin{abstract}
An unprecedented event took place in the Russian Empire in the second half of 1738. In the main square of St. Petersburg, a Jewish merchant, Boroch Leibov, and a Russian navy captain-lieutenant, Alexander Voznitsyn, were burned alive at the stake. Voznitsyn had met Leibov while staying in Moscow. Impressed by the teachings of his new acquaintance, he decided to convert to Judaism. The reason for this decision was probably the mental illness of the captain or his unconfirmed family ties with the fifteenth-century heresy of the Judaizers. Based on the Sobornoye Ulozheniye decree, both of them were sentenced to public burning for withdrawal from the Orthodox faith and blasphemy, in the case of Voznitsyn, and for persuading an Orthodox man to withdraw from his faith, in the case of Leibov. The trial of Boroch and Voznitsyn was widely reported in the whole Russian Empire and became the cause of rapid changes in the policy toward the Jews. Both Empress Anna Ioannovna, and after 1740 her successor, Elizabeth Petrovna, signed a number of decrees ordering the Jews to leave the borders of the Russian Empire.
\end{abstract}

Keywords: trial, burn, Russian Empire, Judaism.

Słowa kluczowe: proces, spalenie, Imperium Rosyjskie, judaizm.

W drugiej połowie 1738 r. w Imperium Rosyjskim doszło do bezprecedensowego wydarzenia z udziałem reprezentanta społeczności żydowskiej. W Petersburgu, na głównym placu miasta, spaleni zostali żywcem na stosie 
Żyd Boroch Lejbow oraz kapitan-lejtnant ${ }^{1}$ floty rosyjskiej Aleksander Woznicyn.

Obszerniejszej informacji na temat całego zdarzenia próżno jednak szukać w polskich opracowaniach dotyczących historii społeczności żydowskiej w Imperium Rosyjskim. Nawet w przetłumaczonej na język polski książce wybitnego rosyjskiego pisarza Aleksandra Sołżenicyna pt. Dwieście lat razem $^{2}$ nie ma w ogóle wzmianki na ten temat. Do jednego zaledwie zdania zostało zmarginalizowane całe zajście u Antony'ego Polonsky'ego w jego monumentalnej pracy dotyczącej dziejów Żydów w Polsce i Rosji. Sprawa Woznicyna i Borocha ani nie została tam poddana analizie, ani umiejscowiona w żadnym szerszym kontekście - czytelnik dowiaduje się jedynie, że w 1738 r. emerytowany oficer floty rosyjskiej, który przeszedł na judaizm, oraz Żyd, odpowiedzialny za namówienie go do tego, zostali spaleni w Petersburgu za swoje wykroczenia ${ }^{3}$.

Zdecydowanie więcej informacji na ten temat znaleźć można w Petnym Zbiorze Praw Imperium Rosyjskiego ${ }^{4}$. Wśród dekretów regulujących status ludności żydowskiej w państwie rosyjskim w XVIII w. znajduje się jeden, który w opisowej i rozbudowanej formie przedstawia przyczyny oraz przebieg procesu dotyczącego odstąpienia od prawosławia i przejścia na judaizm, zakończonego publicznym spaleniem na stosie Borocha Lejbowa i Aleksandra Woznicyna 5 .

Pozornie taki obrót spraw może się wydawać oczywisty. Boroch namówił Woznicyna do porzucenia prawosławia, ten z kolei dokonał obrzezania, po czym bluźnił pod adresem Jezusa Chrystusa i wiary chrześcijańskiej ${ }^{6}$. Po przeanalizowaniu jednak innych źródeł i opracowań dotyczących tego wydarzenia, głównie rosyjskojęzycznych, okazuje się, że sprawa była prawdopodobnie bardziej skomplikowana, niż mogłoby się to początkowo wydawać. Pojawia się bowiem wiele budzących wątpliwości pytań: dlaczego Woznicyn dał się namówić do przejścia na judaizm i czy to możliwe, że inicjatywa wyszła bezpośrednio z jego strony? czy był to jedyny taki

${ }^{1}$ Ranga IX szczebla w Tabeli Rang Marynarskich z okresu panowania carycy Anny Iwanowny Romanowej (1730-1740), współcześnie odpowiada stopniu kapitana.

${ }^{2}$ Aleksander Sołżenicyn, Dwieście lat razem: 1795-1995. Część pierwsza: W przedrewolucyjnej Rosji, Wrocław 2012.

3 Antony Polonsky, The Jews in Poland and Russia, t. 1: 1350-1881, Oxford-Portland 2010, s. 325.

${ }^{4}$ Potnoje Sobranije Zakonow Rossijskoj Impierii, wyd. I, t. 1-45: 1649-1825, red. Michaił Michajłowicz Spieranski, Sankt Petersburg 1830 [dalej: PSZRI (I)].

${ }^{5}$ Ukaz 7612, [w:] PSZRI (I), t. 10: 1737-1739, s. 556.

6 Tamże, s. 556-560. 
przypadek w XVIII-wiecznej Rosji, skoro tylko o nim znalazła się tak obszerna wzmianka w Petnym Zbiorze Praw, czy też akurat to wydarzenie wymagało szczególnego podkreślenia? I w końcu: czy zajście to miało konkretne konsekwencje dla całej diaspory żydowskiej w Rosji? Aby znaleźć odpowiedzi na te pytania, należy przede wszystkim przybliżyć przebieg samego wydarzenia i jego konsekwencje oraz - co wydaje się w szerszej perspektywie konieczne - postaci głównych bohaterów.

Pierwsza wzmianka o Borochu pojawia się już w dekrecie z 14 marca 1727 r., gdzie można przeczytać o wydaleniu go, wraz z drugim Żydem, Lejbowem, poza granice Imperium. $Z$ dużym prawdopodobieństwem można założyć, iż tenże Lejbow był ojcem Borocha, gdyż w późniejszych wzmiankach Boroch figuruje jako Boroch Lejbow, a w tradycji żydowskiej na porządku dziennym było przyjmowanie nazwiska pochodzącego od imienia ojca. Na podstawie wspomnianego dekretu stwierdzić można również, że Boroch i jego ojciec mieszkali w wiosce Zwierowicze ${ }^{7}$ w powiecie smoleńskim i dzierżawili tam opłaty celne i karczemne. W przytoczonym wyżej dekrecie nie podano jednak przyczyn podjęcia decyzji o ich wydaleniu ${ }^{8}$. W tej kwestii pomocny jest dekret z 3 lipca 1738 r., mówiący już konkretnie o sprawie Borocha i Woznicyna. Wynika z niego, że Boroch - poza namówieniem kapitana-lejtnanta Woznicyna do przejścia na judaizm - był zamieszany w inne jeszcze wykroczenia i przestępstwa na terenie samego powiatu smoleńskiego. Można tam także przeczytać, że oskarżano go o nakłanianie prostego ludu do przechodzenia na judaizm, o samowolne wybudowanie synagogi naprzeciwko cerkwi (w oryginale występuje termin „szkoła”), zabicie w Zwierowiczach kapłana Awramija, który czynił mu przeszkody w budowie synagogi, oraz o znęcanie się nad będącą u niego na służbie chrześcijańską chłopką .

$Z$ dużym prawdopodobieństwem można przyjąć, że właśnie powyższe oskarżenia były przyczyną wydalenia Borocha z Rosji. Zostały one jednak tylko wspomniane przy okazji procesu z 1738 r., bez konkretnego umiejscowienia ich w czasie. Za słusznością przyjętego rozumowania przemawiałaby wzmianka o przesłuchaniach z 1723 r., w czasie których mieszczanie i chłopi mieli donieść o wspomnianych przewinieniach Borocha. Oskarżenia te nie zostały potwierdzone, gdyż nie udowodniono mu winy.

${ }^{7}$ Wieś w powiecie smoleńskim. Obecnie (dane z 2007 r.) liczy 127 mieszkańców i znajduje się w obwodzie smoleńskim Federacji Rosyjskiej.

${ }^{8}$ Ukaz 5032, [w:] PSZRI (I), t. 7: 1723-1727, s. 758.

9 Simon Dubnow, Anna Ioannowna, [w:] Jewriejskaja encykłopiedija, t. 8, Sankt Petersburg 1911, s. 593-594. 
Sama władczyni, caryca Anna Iwanowna, przyglądając się sprawie Borocha, stwierdziła, że wspomnianych wydarzeń nie ma potrzeby badać dogłębniej, skoro i tak zostanie on skazany na śmierć w związku z konwersją Woznicyna na judaizm ${ }^{10}$.

W zapisie całej sprawy pojawia się również kilka innych osób pochodzenia żydowskiego. Są to: Szmerl (zięć Borocha), Major z Dubrowny ${ }^{11}$ (syn Borocha), w którego domu doszło do obrzezania i przyjęcia judaizmu przez Woznicyna, oraz trzej inni Żydzi, którzy razem z Borochem mieli namawiać go do przyjęcia „wiary mojżeszowej”. Wśród nich znajdował się wymieniony jedynie z imienia niejaki Fajwist, „który [ponoć był] od Rabinów, to znaczy żydowskich sędziów, błogosławiony na obrzezanie rodzących się od Żydów młodzieńców”, czyli był mohelem, zaproszonym specjalnie w celu obrzezania Woznicyna. W toku procesu mającego udowodnić winę Borocha i Woznicyna Szmerl został uniewinniony, gdyż nie wykazano, aby bezpośrednio brał udział w konwersji tego drugiego na judaizm, pozostali zaś w ogóle nie byli sądzeni, ponieważ mieszkając w miejscowości Dubrowna, znajdującej się na terenie ówczesnej Rzeczypospolitej Obojga Narodów, nie podlegali jurysdykcji Imperium Rosyjskiego ${ }^{12}$.

Oprócz Borocha na śmierć przez spalenie skazany został również Aleksander Woznicyn, kapitan-lejtnant floty. Pochodził on ze starego szlacheckiego rodu związanego z Nowogrodem i wiadomo, że odebrał gruntowne wykształcenie. Jego wuj, Prokofiej Bogdanowicz Woznicyn, należał do wyższej moskiewskiej arystokracji i był znanym dyplomatą, który mógł się poszczycić m.in. doprowadzeniem do podpisania w $1681 \mathrm{r}$. w Bachczysaraju pożądanego rozejmu między Rosją a Turcją ${ }^{13}$. Natomiast jego ciotka została żoną kontradmirała ${ }^{14}$ floty, Iwana Akimowicza Sinjawina, dzięki czemu również przed samym Aleksandrem otworzyła się droga do kariery w rosyjskiej flocie ${ }^{15}$.

${ }^{10}$ Ukaz 7612, [w:] PSZRI (I), t. 10, s. 556-557.

${ }^{11}$ Miejscowość do 1772 r. położona na terenie Wielkiego Księstwa Litewskiego, następnie weszła w skład Imperium Rosyjskiego; obecnie (dane z 2015 r.) liczy 7345 mieszkańców i znajduje się w okręgu witebskim na Białorusi.

${ }^{12}$ Ukaz 7612, [w:] PSZRI (I), t. 10, s. 556-557.

${ }_{13}$ Dwudziestoletni rozejm kończący wojną rosyjsko-turecką, podpisany 13 stycznia 1681 r. w Bachczysaraju na Krymie.

${ }^{14}$ Od 1798 r. ranga IV stopnia w Tabeli Rang Marynarskich; w okresie panowania Anny Iwanowny jej odpowiednikiem był szautbenacht.

${ }^{15}$ Sawielij Dudakow, Paradoksy i priczudy fitosiemitizma i antisiemitizma w Rossii, Moskwa 2000, s. 11-12. 
Woznicyn okazał się jednak człowiekiem chorym umysłowo i wiele jego zachowań było niezrozumiałych i irytujących dla bliskich mu osób. Zdarzyło się na przykład, że bez konkretnego powodu roztrwonił większość swojego majątku. W związku z tym jego siostra skierowała w $1737 \mathrm{r}$. do Senatu Rządzącego ${ }^{16}$ prośbę, aby cały majątek został oddany pod jej opiekę z powodu niepoczytalności brata. Po przeprowadzeniu dochodzenia i określonych badań Senat faktycznie stwierdził u kapitana-lejtnanta oznaki choroby psychicznej i przychylił się do prośby jego siostry, oddając pod jej opiekę większość włości, a samego Woznicyna odprawiając na wcześniejszą emeryturę. Należy podkreślić, że nałożyły się na to również problemy związane z jego żoną, Jeleną Iwanowną, która - podobnie jak duża część otoczenia Aleksandra - nie pałała sympatią do swojego męża. Na wieść o jego chorobie i oddaniu pozostałego majątku pod opiekę nie jej, lecz jego siostrze, żona wręcz go znienawidziła ${ }^{17}$.

W takich okolicznościach w roku 1738 przebywający w Moskwie Woznicyn poznał Żyda Borocha Lejbowa i przystąpił wraz z nim do czytania i interpretowania Biblii (on w wydaniu prawosławnym, Boroch zaś w żydowskim). Będąc pod wrażeniem spostrzeżeń i poglądów swojego nowo poznanego towarzysza, Woznicyn stwierdził, że i on uznaje żydowskie prawo za jedynie słuszne i obowiązujące oraz że w związku z tym chce porzucić wiarę prawosławną i dokonać konwersji na judaizm. W tym celu obaj udali się w podróż do Rzeczypospolitej, gdzie właśnie w Dubrownie, w domu Żyda Majora, Woznicyn wyparł się prawosławia, został obrzezany i - co wyznał na śledztwie - otwarcie bluźnił przeciwko Chrystusowi, Marii oraz wierze chrześcijańskiej ${ }^{18}$.

Całe zajście być może nie wyszłoby na jaw, gdyby nie interwencja żony Aleksandra. Szukając zemsty na swoim mężu za roztrwonienie majątku oraz powierzenie pod opiekę siostrze tego, co z niego pozostało, Jelena Iwanowna, dowiedziawszy się o występku męża, wraz z dwiema służącymi w charakterze świadków złożyła w Kancelarii Synodalnej ${ }^{19}$ w Moskwie donos o jego przejściu na judaizm. Od tego momentu cała sprawa zaczęła nabierać coraz szybszego tempa. Woznicyn - początkowo wraz z Żydem

${ }^{16}$ Organ o kompetencjach administracyjno-kontrolnych i sądowych utworzony przez cara Piotra I w 1711 r. w miejsce Dumy Bojarskiej.

${ }_{17}$ S. Zakusiłło, Aleksandr Artiemiewicz Woznicyn, [w:] Sbornik biografij kawalergardow, t. 1: 1724-1762, red. Siergiej Panczulidziew, Sankt Petersburg 1901, s. 165-167.

${ }_{18}$ Ukaz 7612, [w:] PSZRI (I), t. 10, s. 557-558.

${ }^{19}$ Organ administracyjny pierwszej instancji w przypadku spraw dotyczących wykroczeń o charakterze religijnym. 
Szmerlem - został wezwany przez Kancelarię Synodalną na przesłuchanie. Na tym wstępnym etapie śledztwa nie przyznali się oni jednak do winy, w związku z czym sprawa została przekazana do Kancelarii Tajnych Dochodzeńn ${ }^{20}$. Dopiero tam emerytowany kapitan-lejtnant, poddany torturom, przyznał się do przyjęcia żydowskiej wiary oraz wskazał Borocha Lejbowa jako osobę, która go do tego skłoniła i zaproponowała w tym celu wyjazd do Rzeczypospolitej. Boroch pod wpływem wstępnych tortur również w końcu uznał swoją winę i przyznał, że w początkowym etapie śledztwa próbował zataić fakt dokonania przez Woznicyna obrzezania ${ }^{21}$.

Pomimo wyznania win przez Woznicyna, oczyszczenia duszy i złożenia przysięgi, że już nigdy nie będzie praktykował żydowskiej wiary i obrzędów, w kwietniu 1738 r. sprawa została skierowana do wyższego organu w hierarchii carskiej administracji, tj. do samego Senatu Rządzącego, a konkretnie - do jego Kolegium Sprawiedliwości. Na tym etapie śledztwa obydwaj podejrzani powinni być poddani dalszym przesłuchaniom i torturom w celu ujawnienia całej prawdy. Wciąż nie została bowiem wyjaśniona kwestia tego, czy przypadek Woznicyna był jedynym takim, czy też może jeszcze inni prawosławni porzucili swoją wiarę na rzecz judaizmu, a także czy jeszcze jakieś osoby trzecie były zaangażowane w całą sprawę. Bez tego rodzaju informacji teoretycznie nie można było wydać ostatecznego wyroku, jednak w tym konkretnym przypadku zainterweniowała bezpośrednio sama imperatorowa Anna Iwanowna. Na jej wyraźne polecenie 28 maja 1738 r. dalsze śledztwo zostało zaniechane pomimo sprzeciwu ze strony Kolegium Sprawiedliwości ${ }^{22}$.

Wyrok wydany na obu przestępców był jednoznaczny. Obaj zostali skazani na publiczne spalenie: Boroch na podstawie rozdz. 22. pkt 24. Ułożenia Soborowego ${ }^{23}$, który wyraźnie mówił o karze śmierci dla niewiernego namawiającego $\mathrm{w}$ jakikolwiek sposób osoby wyznania prawosławnego do obrzezania i odstąpienia od swojej wiary ${ }^{24}$, Woznicyn zaś na podstawie rozdz. 1. pkt 1. Ułożenia, przewidującego karę śmierci poprzez spalenie dla tych, którzy dopuścili się bluźnierstwa wobec Świętej Cerkwi

${ }^{20}$ Organ śledczy do spraw wykroczeń o charakterze politycznym, utworzony w $1731 \mathrm{r}$. w miejsce zlikwidowanej w 1726 r. Tajnej Kancelarii; w czasach carycy Katarzyny II zastąpiony przez Tajną Ekspedycję.

${ }_{21}$ Zakusiłło, Aleksandr Artiemiewicz Woznicyn..., s. 166.

${ }^{22}$ Tamże.

${ }_{23}$ Zbiór praw obowiązujących w Carstwie Rosyjskim przyjęty w 1649 r. za panowania cara Aleksego Michałowicza.

${ }^{24}$ Utożenije, rozdz. 22, pkt 24, [w:] PSZRI (I), t. 1: 1649-1675, s. 156. 
i wiary chrześcijańskiej ${ }^{25}$. Co ciekawe, żona Woznicyna, która doniosła władzom o zaistniałej sytuacji, po śmierci męża otrzymała, za słuszny donos, odpowiednią część z jego ruchomego i nieruchomego majątku oraz dodatkowo - „do 100 dusz poddanych wraz z ziemiami i innymi przynależnościami”26.

Tragiczny dla skazanych finał opisanej sprawy może być interpretowany w szerszym kontekście niż tylko jednostkowe odstąpienie chrześcijanina od swojej religii pod wpływem przebiegłego Żyda. Aby go zrozumieć, należy odwołać się do cytowanej już pracy rosyjskiego historyka Sawielija Dudakowa pt. Paradoksy i priczudy fitosiemitizma i antisiemitizma $w$ Rossii. Odnosząc się do opisywanego tu wydarzenia, autor wyraźnie podkreślił, że proces obydwu skazanych odbył się w przyśpieszonym tempie, nie został przeprowadzony do końca, a wymierzona kara była bardzo surowa. $\mathrm{Z}$ jakiejś przyczyny caryca Anna Iwanowna nie chciała, aby się on przeciągał i aby być może nowe fakty nie wyszły na jaw ${ }^{27}$.

Należy tu jeszcze raz przywołać pozornie mało istotny fakt z życia Aleksandra Woznicyna. Otóż zarówno on, jak i członkowie całego jego rodu pochodzili z Nowogrodu. Z punktu widzenia badacza historii Żydów w Rosji jest to miasto niezwykle ważne, gdyż właśnie tam pod koniec $\mathrm{XV}$ w. narodziła się herezja tzw. judaizantów, która swoim zasięgiem objęła szerokie warstwy duchowieństwa prawosławnego oraz tamtejszego możnowładztwa i zyskała sobie potężnych protektorów na samym dworze carskim. Ostatecznie herezję udało się zażegnać w 1504 r., jednak - jak twierdzą niektórzy badacze - niewielka część jej wyznawców zdołała przetrwać w ukryciu aż do XVII w. ${ }^{28}$ Wspomniany Sawielij Dudakow snuje w związku z tym domysły, jakoby właśnie widmo powrotu herezji, która być może w podziemiu przetrwała aż do XVIII w., miało skłonić carycę Annę Iwanownę do tak szybkiego i surowego zakończenia śledztwa. Zostaje to przyrównane do przypadku marranów, którzy na Półwyspie Iberyjskim przez wiele wieków w ukryciu przed światem pielęgnowali religię swoich

${ }^{25}$ Tamże, rozdz. 1, pkt 1, s. 3.

${ }_{26}$ Zakusiłło, Aleksandr Artiemiewicz Woznicyn..., s. 166-167.

${ }_{27}$ Dudakow, Paradoksy i priczudy..., s. 11-12.

${ }_{28}$ Władisław Masalski, Żydowstwujuszczije, [w:] Encykłopiediczeskij słowar', t. 11A, Sankt Petersburg 1894, s. 943-944. 
przodków i później, w sprzyjających okolicznościach, niejednokrotnie do niej wracali ${ }^{29}$.

Nie ma jednoznacznych dowodów na to, że rodzina kapitana-lejtnanta Aleksandra Woznicyna miała w przeszłości związki z herezją judaizantów, podobnie jak nie można z całą pewnością założyć, iż sam skazany, przechodząc na judaizm, chciał pielęgnować domniemaną tradycję swoich przodków. Można jednak też przypuszczać, że chory umysłowo Woznicyn dał sobie wmówić, że w przeszłości jego przodkowie byli w jakiś sposób związani z sektą skłaniającą się w stronę judaizmu, i w ten sposób został przez Borocha zachęcony do konwersji. Wątpliwości co do jego pochodzenia i motywów nie miał jednak rosyjski filozof Włodzimierz Sołowjow, według którego cała sprawa miała być ostatnim przejawem inkwizycji w Europie, swoistym auto da fé, ostatnim religijnym spaleniem na starym kontynencie ${ }^{30}$.

Bez wątpliwości natomiast pozostaje fakt, że zarówno dla carycy Anny Iwanowny, jak i dla sfer rządzących w Imperium Rosyjskim sprawa Borocha i Woznicyna jednoznacznie niosła ze sobą widmo powrotu herezji judaizantów. Wywołało to wśród elit kraju, podobnie jak wśród XVIi XVII-wiecznych władców moskiewskich, reakcję obronną, rozbudziło zakorzenioną już wcześniej judeofobię oraz strach przed napływem do ich państwa ludności żydowskiej ${ }^{31}$. Efektem był drastyczny zwrot w polityce Imperium wobec Żydów.

Panowanie Anny Iwanowny początkowo zapowiadało pewną odwilż w stosunku do wyznawców judaizmu i kwestii ich przebywania w Imperium Rosyjskim. Już dekret z 1728 r., wydany jeszcze przez jej poprzednika, Piotra II, pozwalał żydowskim kupcom na swobodny wjazd do Małorosji na jarmarki i w celach handlowych z zastrzeżeniem, że muszą sprzedawać swoje towary hurtem i nie mogą osiedlać się w tym kraju ${ }^{32}$. Kolejne dekrety, wydawane pod panowaniem Anny Iwanowny, poszerzały ten obszar ograniczonej swobody. W 1731 r. ukaz Senatu Rządzącego rozszerzył obszar czasowego pobytu Żydów również na Smoleńsk, a trzy lata później, w 1734 r., imienny dekret imperatorowej poszerzał strefę handlu dla kupców żydowskich również o tereny Ukrainy Słobodzkiej (czyli terytorium znajdujące się na północny wschód od Połtawy). W dalszym ciągu

\footnotetext{
${ }^{29}$ Dudakow, Paradoksy i priczudy..., s. 12.

30 Tamże, s. 13.

${ }^{31}$ Dubnow, Anna Ioannowna..., s. 593.

32 Ukaz 5324, pkt 14, [w:] PSZRI (I), t. 8: 1728-1732, s. 80.
} 
podtrzymywany był zakaz stałego osiedlania się w granicach Imperium, jednak zdaje się, że władze nieoficjalnie przymykały na to oko ${ }^{33}$.

Radykalną zmianę w polityce wobec Żydów zaobserwować można właśnie po roku 1738. W wyniku procesu Borocha i Woznicyna odżywa z nową siłą rosyjska judeofobia. Druga połowa panowania Anny Iwanowny, aż do jej śmierci w 1740 r., naznaczona została dekretami o charakterze wyraźnie antyżydowskim. 11 lipca $1740 \mathrm{r}$. wydane zostało rozporządzenie nakazujące wydalenie wszystkich Żydów poza granice Rosji oraz zakazujące im przyjeżdżania do niej w jakimkolwiek celu. Do rozporządzenia dołączono również listę, która dokładnie przedstawiała, ilu Żydów aktualnie znajdowało się w poszczególnych włościach na terenie Małorosji, określając łączną ich liczbę na 573 osoby ${ }^{34}$.

Podobne dekrety ukazały się również za panowania kolejnej carycy, Elżbiety Piotrowny. Jej rozporządzenie z 1742 r. nakazywało wygnanie z mało- i wielkorosyjskich miast i wsi wszystkich Żydów wraz z całym ich dobytkiem i bez względu na płeć, chyba że zdecydowaliby się przyjąć prawosławie ${ }^{35}$. Z kolei w $1744 \mathrm{r}$. imperatorowa bezwarunkowo odrzuciła sprzeciw niektórych rosyjskich środowisk kupieckich zainteresowanych dopuszczeniem Żydów do handlu w zachodnich prowincjach cesarstwa, a 25 stycznia tegoż roku Senat Rządzący przyjął dekret $O$ wydaleniu za granicę Żydów z Małej i Biatej Rosji i pozostatych zawojowanych miast i niezezwalaniu na ich przyjeżdzanie do Rosji, nawet w celach handlowych na jarmarki $i^{36}$. Był to jednocześnie ostatni dotyczący ludności żydowskiej ukaz wydany przed wstąpieniem na tron Katarzyny II w 1762 r.

Proces Żyda Borocha i kapitana-lejtnanta Woznicyna nie był zatem mało znaczącym wydarzeniem związanym $\mathrm{z}$ historią diaspory żydowskiej w Rosji. Pociągnął on za sobą określone konsekwencje dla tej grupy ludności, doprowadzając do obrania przez rządzących państwem rosyjskim zdecydowanie ostrzejszego kierunku w polityce wobec Żydów. Ukazujące się wtedy rozporządzenia nakazujące usuwanie Żydów z kraju były wdrażane w życie - w przeciwieństwie do dekretów wydanych przed rokiem 1738. Przykładowo, w 1743 r. z samej tylko Małorosji zostało usuniętych 142 wyznawców judaizmu, zarówno kobiet, jak i mężczyzn ${ }^{37}$.

\footnotetext{
${ }^{33}$ Ukaz 5852, [w:] PSZRI (I), t. 8, s. 545; Sołżenicyn, Dwieście lat razem..., s. 22.

${ }^{34}$ Ukaz 8169, [w:] PSZRI (I), t. 11: 1740-1743, s. 183-185.

${ }^{35}$ Ukaz 8840, [w:] PSZRI (I), t. 11, s. 981.

${ }^{36}$ Ukaz 8867, [w:] PSZRI (I), t. 12: 1744-1748, s. 21.

${ }^{37}$ Ukaz 8840, [w:] PSZRI (I), t. 11, s. 981.
} 
Sprawa Borocha i Woznicyna miała niewątpliwie podłoże religijne i - zachowując pewien dystans - można by ją nazwać, za Włodzimierzem Sołowjowem, ostatnim auto da fé w Europie. Wydarzenie to nie tylko odbiło się szerokim echem w Imperium Rosyjskim już w XVIII w., lecz także jeszcze długo później żyło w świadomości mieszkańców tego państwa i w pewien sposób zapisało się również w jego kulturze. Już w kilka lat po pamiętnym spaleniu wspomnianych oskarżonych odwoływał się do wydarzeń z roku 1738 poeta Antioch Kantemir, a w wieku XX Leontij Josifowicz Rakowski na ich podstawie napisał powieść historyczną pt. Izumlennyj kapitan [Odurzony kapitan] ${ }^{38}$.

\section{Aneks źródłowy}

Ukaz 7612 z 3 lipca 1738 roku. Najwyższa rezolucja na referat Senatu. O spaleniu kapitana-lejtnanta floty Woznicyna za odstapienie od chrześcijańskiej wiary, a Żyda Borocha za nawrócenie owego kapitana na żydowska wiarę.

Referat. Minionego 20 kwietnia tegoż 1738 roku zgodnie z poleceniem z Kancelarii Tajnych Dochodzeń przysłany do Senatu, na mocy Imiennego Waszej Imperatorskiej Mości, wydanego tegoż dnia 18 kwietnia ukazu, do sądu cywilnego, morskiej floty kapitan-lejtnant w stanie spoczynku Aleksander Woznicyn, Żyd Boroch Lejbow oraz zięć owego Borocha Żyd Szmerl i autentyczna o nich sprawa śledcza, dla rozpatrzenia, o nawróceniu owego Woznicyna z prawosławia na żydowską wiarę i o bluźnierczych Woznicyna słowach, w czym, na mocy obwieszczonego przez Waszą Imperatorską Mość Imiennego ukazu, rozkazano z nimi postąpić na mocy praw i ukazów.

I dnia 21 kwietnia, na podstawie rezolucji Senatu, wymienieni Woznicyn i Żyd Boroch Lejbow, i zięć jego Żyd Szmerl, z autentyczną o nich sprawą, zostali odesłani do Kolegium Sprawiedliwości i rozkazano owemu, rozpatrzywszy i wybadawszy zgodnie z prawami i ukazami, podpisać sentencję i dla aprobacji podać do Senatu.

27 kwietnia, na podstawie rezolucji Senatu, przysłaną z Kancelarii Tajnych Dochodzeń autentyczną sprawę o śmiertelnym zabójstwie przez wspomnianego Żyda Borocha kapłana Awramija ze wsi Zwierowicze w powiecie smoleńskim i o innych [występkach] odesłano do tegoż

38 Dudakow, Paradoksy i priczudy..., s. 13. 
Kolegium i rozkazano owemu niezwłocznie sprawdzić, czy nie należy w tej sprawie zbadać czegoś dodatkowo, i podpisawszy sentencję, podać niezwłocznie do Senatu razem ze wspomnianą sentencją o nawróceniu Woznicyna na żydowską wiarę.

A dnia 2 maja owe Kolegium doniosło do Senatu: wspomnianych Woznicyna i Żyda Borocha, tak w pierwszej, o nawróceniu i obrzezaniu owego Woznicyna na żydowską wiarę i o bluźnierczych jego słowach, jak w drugiej sprawie, o zabójstwie przez owego Żyda Borocha Lejbowa kapłana i w nawracaniu z innymi Żydami w Smoleńsku prostego narodu [na żydowską wiarę], i w wybudowaniu im żydowskiej szkoły, i w męczeniu będącej u niego w służbie rosyjskiej chłopskiej dziewki, na mocy Ułożenia, w celu ustalenia najwyższej prawdy, należy stanowczo przesłuchać, a bez przeprowadzenia wskazanych przesłuchiwań żadnej sentencji Kolegium podpisać nie może.

A 10 maja Generał i Kawaler Uszakow oznajmił w Senacie: że Wasza Imperatorska Mość Najmiłościwsza zażyczyliście sobie rozsądzić, że chociaż on, Boroch, podlega przesłuchaniom, jednak żeby ze zmiennych wypowiedzi, które mogą wystąpić od niezniesienia ciężkich przesłuchiwań, nie nastąpiło w sprawie Woznicyna zbytnie przedłużenie, należy wydać wyrok, prawnie należny za owe Woznicyna nawrócenie [na żydowską wiarę], nie przesłuchując Borocha.

Ze względu na to, na podstawie rezolucji Senatu z 16 maja i przekazanego do Kolegium Sprawiedliwości ukazu, rozkazano o nich, Żydzie Borochu Lejbowie i Woznicynie, i o Żydzie Szmerlu, temuż Kolegium, nie wypytując i nie przesłuchując ich, czego oni na mocy praw godni, podpisać sentencję i podać do Senatu dla aprobacji.

Owe Kolegium na podstawie dochodzenia i sądu przedstawia ${ }^{39}$ :

1. Wspomniany Woznicyn podlega karze śmierci, spalony ma być, dlatego iż: w Kancelarii Tajnych Dochodzeń, po przyprowadzeniu go 22 marca do sali tortur, Woznicyn przyznał się do winy i wyznał, że żydowską wiarę utrzymywał i zapragnął przyjąć obrzezanie on, Woznicyn, będąc pouczonym w tej kwestii przez wspomnianego Żyda Borocha, po uzgodnieniu z Borochem, w celu obrzezania i lepszego poznania żydowskiej wiary pojechał Woznicyn z Moskwy do Polski i mieszkał w Dubrownie w domu syna owego Borocha, Żyda Majora, do którego to domu Boroch przyprowadził trzech Żydów, a imion ich nie spamięta, i po licznych od

${ }^{39} \mathrm{~W}$ oryginale punkty 1, 2, 3 i 4 były zapisane tekstem ciągłym, bez akapitów. 
owych Żydów przekonywaniach i pouczaniach Woznicyn przyjął obrzezanie, a obrzezywał go jeden $\mathrm{z}$ wyżej wspomnianych, przyprowadzonych przez Borocha Żydów. A przy tym wszystkim był ów Boroch i syn jego Major, i po obrzezaniu wspomniani Żydzi z owym Borochem i jego synem, zgodnie z żydowskim obrzędem, spożywali obiad, a Woznicyn od obrzezania zaniemógł i leżał na łóżku swoim; a żydowskie szabasy i bluźniercze przeciwko Jezusowi Chrystusowi, Panu Bogu naszemu, słowa, o których na niego, Woznicyna, ludzie jego zeznali, o czym w sprawie wskazano dokładnie, on, Woznicyn, wygłaszał bez żadnego zamiaru poprzez prostotę [ciemnotę] swoją, i po pouczeniu do tego od wyżej wskazanych przyprowadzonych przez Borocha dla obrzezania Woznicyna trzech osób, Żydów, nie uznawał on, Woznicyn, Chrystusa Pana jako prawdziwego Boga; tak i z podniesienia na koło on, Woznicyn, o wyżej wspomnianym mówił podobnie jak i poprzednio ze skruchą zgłaszał, a najpierw w odpowiedziach swoich winy swojej on, Woznicyn, nie uznał, myśląc, że o obrzezaniu jego nikt nie może się dowiedzieć, i lękał się za to dla siebie wielkiej męki; a dzisiaj o wszystkim wyżej wspomnianym czystą winę swoją zgłasza, oczyszczając duszę swoją, i na przyszłość żydowskiej wiary i obrzędów ich [Żydów] utrzymywać on nie będzie. Na podstawie tego, Woznicyna świadome i pożądane, po żydowskim pouczeniu, z prawosławia na żydowską wiarę przejście i obrzezanie oraz wygłaszane przez niego bluźniercze słowa jasno ujawniły się. A według Ułożenia, 1. rozdział, 1. punkt: „Jeżeli będzie kto z innowierców lub nawet ruski człowiek bluźnierstwa mówić wobec Pana Boga i Zbawiciela naszego Jezusa Chrystusa albo wobec Przenajświętszej Pani naszej Bogurodzicy i Zawsze-dziewicy Marii, albo świętego krzyża, albo na świętych, tego bluźniercę, napiętnowawszy, stracić, spalić”. A chociaż on, Woznicyn, po zdjęciu go z koła, w Tajnej Kancelarii dnia 22 [marca], w uzupełniającym wypytywaniu, z wyżej obwieszczoną skruchą, powiedział tegoż dnia w katowni o tym, że jakoby wspomniany Boroch do domu syna swojego przyprowadził Żydów, troje ludzi, z których jeden go obrzezał, i o mówieniu jemu, Woznicynowi, przez trzech Żydów, że nowemu prawu, danemu przez Ukrzyżowanego, wierzyć nie trzeba. Również wspomniane istotne, bluźniercze słowa jakoby wymawiał on, Woznicyn, bez żadnego zamiaru, poprzez prostotę [ciemnotę] swoją, że po pouczeniu przez tych Żydów nie uznawał on, Woznicyn, Chrystusa Pana jako prawdziwego Boga. Wyznał on, Woznicyn, przeraziwszy się, pośpiesznie i to, że on, Woznicyn, wyznał jawną nieprawdę i uczynił w tym umyślne wypieranie się, chcąc 
uniknąć za to kary śmieci. Następnie wspomniany Żyd Boroch Lejbow tegoż 23 marca w Tajnej Kancelarii w wypytywaniu o naradzie swojej z owym Woznicynem, o żydowskiej wierze i o czytaniu przez nich Biblii, przez Woznicyna rosyjskiej, a przez Borocha żydowskiej, i o opowiadaniu przez Woznicyna Borochowi o tym, że on, Woznicyn, uznaje żydowskie prawo za słuszne, i o chęci Woznicyna w prawie żydowskim obrzezać się, i o innych [rzeczach], napisanych w tym raporcie, wyznał właśnie. W tym zaś wypytywaniu oświadczył on, Boroch, że ów Woznicyn o podtrzymaniu [zamiaru] obrzezania swojego, w świetlicy syna Borocha, złożywszy ręce swoje, przysięgał; i on, Boroch, widząc taką Woznicyna przysięgę, wezwał do domu swojego syna znajdującego się w Dubrownie Żyda Fajwista, on zaś nazywa się Piejwisz, który [ponoć był] od Rabinów, to znaczy żydowskich sędziów, błogosławiony na obrzezanie rodzących się od Żydów młodzieńców, i ów Woznicyn dał temu Fajwistowi 10 rubli, i prosił go, aby zgodnie z żydowskim prawem jego, Woznicyna, obrzezał, przy której to Woznicyna prośbie i on, Boroch, temu Żydowi Fajwistowi mówił, aby on tegoż Woznicyna obrzezał i niczego przy tym nie obawiał się, a on, Boroch, uczynić to pozwala. I wtedy zaś ów Żyd Fajwist jego, Woznicyna, jak według prawa ich należy, obrzezał; a Woznicyn o przysiędze swojej, o fakcie obrzezania swojego i o daniu Żydowi Fajwistowi 10 rubli nie tylko w wypytywaniu, ale i w uznaniu winy swojej, zamykając swoje bluźniercze, wyżej opisane sprawy, nie wskazał, ale utajnił. Jednakowoż owym Borochowym świadectwem został on nader zdemaskowany, po czym już żadne jego zatajnienia i odrażające wykręty nie usprawiedliwiają go, ale nadspodziewanie wskazują na jawną winę, i godzien on, za wykazane jego winy, wspomnianej kary śmierci. A gdyby on, Woznicyn, przejście z prawosławia na żydowską wiarę i obrzezanie siebie niesamowolnie uczynił, ale jakimikolwiek środkami poprzez kogoś przemocą albo oszustwem do tego doprowadzony był, takie przypadki, na mocy Ułożenia, 22. rozdział, punkt 24., rozkazano odsyłać w celu uczynienia ukazu, na zasadach Świętych Apostołów i Świętych Ojców, do Patriarchy lub do innej władzy; a ów Woznicyn, jak wyżej zeznano, uczynił to na własne samowolne życzenie, mając naradę z Żydami; na mocy którego to punktu Woznicyn, nie będąc przymuszonym siłą ani oszukanym, godzien jest spalenia. Zaś poza tym, wygłaszał Woznicyn istotne i Świętej Cerkwi przeciwne bluźniercze słowa, które to bluźnierstwo, choćby i innych jego wstrętnych spraw nie było, wystarczy, aby na mocy wyżej wspomnianego 1 . rozdziału 1. punktu on, Woznicyn, od kary śmierci uwolniony być nie mógł. 
2. Wspomniany Żyd Boroch Lejbow godzien zaś jest kary śmierci poprzez spalenie, ponieważ: (dnia 23 marca 1738 roku w Kancelarii Tajnych Dochodzeń w rozpytywaniu wyznał on), że sprowadzając owego Woznicyna z prawosławia do swojej żydowskiej wiary, naradzał się z nim Woznicyn w czasie pobytu ich w Moskwie o żydowskim prawie i czytali Biblię, Woznicyn rosyjską, a Boroch żydowską, i przez tę namowę i pouczenie Żyda Borocha ów Woznicyn z Moskwy wyjechał; a w czasie pobytu owego Woznicyna w Polsce, na polecenie Borocha, ów Woznicyn o utrzymywaniu żydowskiego prawa przysięgał i potem, po namowie Borocha, Żyd Fajwist Woznicyna obrzezał i po obrzezaniu spożyli obiad przygotowany za otrzymane od Woznicyna pieniądze; a w Moskwie w Kancelarii Synodalnej o wszystkim wyżej wspomnianym ów Boroch nie oznajmił i winy swojej w tym nie złożył [przyznał], chcąc o obrzezaniu tegoż Woznicyna zataić. A w Ułożeniu, rozdział 22., punkt 24., rozkazano: „Jeśli będzie bisurman [poganin] jakimikolwiek środkami, przy użyciu przemocy czy oszustwa, ruskiego człowieka do swojej bisurmańskiej wiary przymuszał i obrzeza, to tego bisurmana po ściganiu stracić, spalić”. I na mocy tegoż punktu Ułożenia ów Boroch tej egzekucji podlega, aby na przyszłość innym takie rzeczy robić raz na zawsze się odechciało i aby nieświadomi ludzie, patrząc na egzekucję wywrotowca i podżegacza, [mamiącego] według diabelskich wskazówek poprzez wdzięk i oszustwo, tegoż i Żyda Borocha, wystąpiwszy jakoby pod pozorem słuszności i prawdy, nie zostali odwróceni od prawosławnej wiary, która ponad wszystko dochowana być powinna.

3. Co zaś tyczy się Żyda Borocha Lejbowa w sprawie śmiertelnego zabójstwa kapłana Awramija i nakłaniania przez owego Żyda Borocha wraz z innymi Żydami do swojej wiary prostego ludu w Smoleńsku, i wybudowania przez nich żydowskiej szkoły [synagogi], i innych doniesień przedstawionych w tej sprawie przez mieszczan smoleńskich, Gerasima Szyły, Siemiona Paskina, i w sprawie męczenia przez Borocha zatrudnionej u niego, [pochodzącej] ze Zwierowickiej włości, wsi Kobylaków, chrześcijańskiej dziewki, o czym dowiedziano się od tej dziewki, i o reszcie [rzeczy wykazanych] przez chłopów ze Zwierowickiej gminy i od mieszkańców wsi Zwierowicze, Fiskala, starostów i popów, i mieszczan podczas dochodzeń przeprowadzonych w 1723 roku przez Fiłofieja, Arcybiskupa Smoleńskiego i Dorohobużskiego, jako że spraw tych jeszcze nie badano, tak i badać tego, jeśli owemu Żydowi w opinii tegoż Kolegium kara śmierci ma zostać wymierzona, nie ma potrzeby. 
4. Wzmiankowany w wyżej opisanej sprawie o Woznicynie i Żydzie Borochu Żyd, owego Borocha zięć, Szmerl, według tegoż Kolegium powinien zostać uwolniony z tej przyczyny, że dla tej sprawy nie jest istotny i zgody jego na przemianę Woznicyna na żydowską wiarę tak od Woznicyna, jak i od Żyda Borocha nie wykazano.

A ponieważ, według Imiennego Waszej Imperatorskiej Mości ukazu, danego Senatowi 9 czerwca [lipca?] minionego 1735 roku, żadnych Waszej Mości słownych Imiennych ukazów oprócz tych, które osobistym podpisaniem ręką Waszej Imperatorskiej Mości lub rękami wszystkich Waszej Imperatorskiej Mości Gabinet-Ministrów będą [poświadczone], przyjmować i w życie wcielać nie nakazano, a jeżeli od kogo jakie słowne ukazy gdzieś ogłoszone będą, to ma się o nich raportować do Gabinetów Waszej Imperatorskiej Mości. Ze względu na to Senat o wyżej wspomnianym obwieszczeniu Generała i Kawalera Uszakowa o nieprzesłuchiwaniu wspomnianego Żyda Borocha Lejbowa wiernopoddańczo Waszej Imperatorskiej Mości donosi i domaga się na owe Najwyższego Cesarskiego Waszej Imperatorskiej Mości potwierdzenia, a przy tym wiernopoddańcze swoje zdanie podnosi: że owych, Żyda Borocha Lejbowa i Woznicyna, dla uzyskania prawdy należy poddać wskazanym przesłuchaniom, by dowiedzieć się, czy nie wskaże ów Boroch kogoś ze wspólników w nawróceniu jeszcze i innych z pobożnej wiary greckiej na żydowską wiarę i w innych przeciwnych Wschodniej Cerkwi sprawach; a jeśli uczynić im egzekucję bez śledztwa, to winni, przez nich obecnie ukrywani, moga pozostać bez odpowiednich za ich winy katuszy i przesłuchiwać już nie będzie kogo. Jeśli zaś Wasza Imperatorska Mość Najmiłościwsza raczy nakazać ową sprawę rozwiązać, nie przesłuchując Borocha i Woznicyna, to Senat zgodzi się z opinią Kolegium Sprawiedliwości, że za wykazane ich, Borocha i Woznicyna, istotne winy, na mocy wyżej wzmiankowanych dokładnych punktów Ułożenia, należy ich publicznie stracić ciężką karą śmierci, spalić; i na to Waszą Imperatorską Mość Senat wiernopoddańczo prosi [o wydanie] Najmiłościwszego ukazu.

Rezolucja. Dlatego że oni, Woznicyn do bluźnienia na Chrystusa Zbawiciela naszego i do wzgardzenia prawdziwą chrześcijańską wiarą, i do przyjęcia żydowskiej wiary, a Żyd Boroch Lejbow do nawrócenia go poprzez zachęcające swoje namowy na żydostwo, sami przyznali się; dlatego więcej ich przesłuchiwać nie ma po co, aby owa przeciwko Bogu sprawa nie była kontynuowana i także aby bluźnierca Woznicyn i nawracający na żydostwo Żyd Boroch innych urzekać nie ośmielili się; dlatego za takie ich, Bogu 
przeciwne winy, bez dalszego odwlekania, na mocy państwowych praw, obu stracić śmiercią przez spalenie, aby inni, patrzący na to ignoranci i bogoprzeciwnicy, od chrześcijańskiej wiary odstąpić nie mogli, a tacy zachęcający jak ów Żyd Boroch z chrześcijańskiej wiary kusić i na swoją wiarę nawracać odwagi nie mieli. A Żyda Szmerla, który do tej sprawy niczym nie przyłożył się, uwolnić.

Maciej Szkótka

mac.szkolka@gmail.com 